\title{
Excessive Masculinity: Boxer Narratives in Holocaust Literature
}

DOI: 10.18318/td.2017.en.2.13

\section{Konzentrationslager Las Vegas}

"Guys fight to the death. It's not right, but it's «Dog House» rules" - these words could belong to Kurt Franz, one of the commanders of KZ Treblinka, who practiced boxing on his powerless prisoners, or to Walter Dunning, a kapo from Auschwitz, who often took part in boxing matches organized in the camp. But, these are the words of Floyd Mayweather Junior, a contemporary licensed boxer and professional boxing promoter in the state of Nevada, who, in light of his licenses and in contrast to hegemonic rulers and masters of the lager, is bound by numerous, clearly stated sporting rules, which are regulated by state laws. As well as by a particular, though - as I will attempt to show - not at all intuitive, ethic of a "manly sport."

Mayweather spoke these words in September 2014, on an All Access television program, which featured, among other things, scenes from his boxing club in Las Vegas, called the "Dog House" by the boxer." The champion

1 The official name is different - "Mayweather Boxing Club" - but the boxer himself refers to it as "The Dog House," having on his mind either the place itself or the rules which apply there.
Paweł Wolski -

Assistant Professor

at the Institute of

Culture and Polish

Literature Studies,

University of

Szczecin. Co-editor

of Autobiografia.

Literatura. Kultura.

Media magazine. He

recently published:

Wstręti Zagłada.

Nowoczesność

Tadeusza Borowskiego

(2018) [Disgust and

the Holocaust. The

Modernity of Tadeusz

Borowski], Tadeusz

Borowski - Primo

Levi. Prze-pisywanie

literatury Holocaustu

(2013). [Tadeusz

Borowski - Primo Levi.

Re-Writing Holocaust

Literature]. His

research interests

encompass literary

representations of

bodily experience of

the Shoah. Contact:

pawel.wolski@univ.

szczecin.pl 
exaggerated only slightly in his reference to death - the program shows a sparring of Sharif Rahman with Donovan Cameron, which lasts a single, although thirty-minute-long round, which ends only when the latter of the two boxers has no more strength to keep fighting on. For this reason the boxing commission of the State of Nevada decided to investigate the case. Mayweather, who is bound by sporting rules, organized a fight which contradicts them. What is worse, he paraded on the same program in the company of numerous scantily dressed girlfriends who smoked marihuana. He did everything that might be expected from a boxer, that is, most of all, he praised a heroic disregard for death and emanated sexual and ethical promiscuity things to which the boxer himself cannot ever openly admit. Not a boxer who is bound by rules, that is. ${ }^{2}$

Rules in modern boxing are a fairly new phenomenon. Their authorship is attributed to the 9th Marquess of Queensberry, John Sholto Douglas. They were adopted by British boxers around 1866, but the first writtendown rules of the sport were drawn up over a hundred years earlier, in 1743, by a London rafter and boxer, John Broughton, who thanks to his boxing fame opened his own amphitheater. This is worth mentioning, as the history of boxing is believed to have started with the drafting of rules by the Marquess, who therefore transformed former street-fights into a sport that in itself is an activity devoid of any practical aim and therefore gains due to this lack of a teleological nature - a noble, sacred dimension. Rules introduced by Broughton were not as much motivated by the need of adding some nobility to the sport, which, by the way, from its beginnings in the eighteenth-century was commonly, and prior to any formal regulation, called an art ("art of bruising" or "sweet science"; both terms refer to art and science in their premodern understanding as "techne"), but most of all resulted from the need to create a common ground for settling disputes over monetary bets. ${ }^{3}$ In Broughton's rules the paragraph disallowing beating of a person who is down, and punches beyond the waist, was lower in the hierarchy of rules than the paragraph setting the way of distributing the proceeds from the fight (the winner was to receive two-thirds of the

2 Mayweather was deposed on September 23rd, 2014. He did not testify under oath. For this reason many experts commenting on his case (among them, writer and sports journalist Thomas Hauser, in his official blog) doubt the sincerity of his arguments - otherwise highly interesting from a narrative standpoint. According to the boxer, there were several breaks in the over half-hour-long round that were removed in post-production of the episode, and the marihuana smoked by the women invited to his house was merely a stage prop. 
stakes). ${ }^{4}$ Boxing as a sporting activity has therefore undergone probably the same process as most other areas of art - from a preindustrial and teleological form (fist-fights in the Middle ages - Polish "kułajki" - probably were, like rochwist, which was a kind of horse-racing, a way of choosing rulers and solving conflicts. ${ }^{5}$ Erasmus of Rotterdam in his Colloquies asserts that "We must play for s o m e stake or else the game will lag."6 In the seventeenth century "all popular games - football, boules, croquet, bowling - are based on bets. Being a primal form of a game, wagers provide a minimum of respectability"7), to a form ruled by the logic of capitalism. The metamorphoses of boxing are a reflection of the mechanism of this formation, of which the fetishizing of the body as a commodity and the specialization of categories in which it is understood are probably the clearest examples. In contemporary boxing this manifests, among other things, through the creation of weight categories (they existed previously but as an approximation, an arbitrarily determined figure; the rules set out by the Marquess of Queensberry merely required respecting the categories and not their scrupulous safeguarding, to the very last gram), ${ }^{8}$ and through world championships sponsored by innumerable sanctioning organizations. In short, boxing today is a fully developed element of late capitalist culture - an expert culture that considers the necessities of economy to be a basic mode of thinking, ${ }^{9}$ which accommodates cruelty and irrationality within an economic epistemological model that considers excess to be a form of more or less quantifiable data, therefore dispelling the aspect of unacceptability it might have possessed:

The vilest forms of human decision-making and behavior - torture by sadists and overt and covert foreign intervention by government leaders - are now for all of us comprehensible [...], whatever we think of them.10

4 Ibid., 31.

5 Wojciech Lipoński, Historia sportu na tle rozwoju kultury fizycznej (Warszawa: PWN, 2012) 189-192.

6 Desiderius Erasmus, Colloquies, trans. Craig R. Thompson (Toronto: University of Toronto Press, 1997), 76.

7 Georges Vigarello, "Ćwiczyć, grać," in Historia ciała, vol. 1: Od renesansu do oświecenia, ed. Georges Vigarello, trans. Tomasz Stróżyński (Gdańsk: słowo/obraz terytoria, 2011), 239.

8 Boddy, Boxing, 92.

9 Fredric Jameson, Postmodernism, or, the Cultural Logic of Late Capitalism (Durham: Duke, 2003).

10 Ibid., 268. 


\section{Limits of Sport. Limits of Genocide}

It therefore seems that the previously quoted opinion of Floyd Mayweather Junior - nicknamed "Money," as he is the world's highest-paid athlete should not be considered aberrant in the context of boxing, which is understood in the way described above. This sentence, alongside another expressed on the same program ("It's about pushing these fighters to the limit. And when we say push it to the limit, which will you believe - there's no limit"), becomes a definition of postmodern sport as an emanation of a technicized approach to reality ("the viewer partaking in a [sport] spectacle is no longer immersed in a moving crowd but in an infinite sequence of references and numbers"11). At the same time it aptly points out the fundamental difficulty sport as such - and combat sports in particular - poses for culturally oriented definitions of categories such as the body, femininity, and masculinity. Sport, employing the category of boundary as its ontic cornerstone (there are numerous boundaries fundamental for sport, such as: the distinction between winner and loser, winners in respective weight or age categories, and the like; between female, male, and intersexual competitors; between able and disabled players - who often partake in separate games and competitions, often in disciplines that have no equivalent in non-disabled sport ${ }^{12}$ ), is built on the idea of overcoming boundaries. Peter Sloterdijk summed this up pointedly, though not necessarily having only sport in mind:

The definition of the trainer is that they want the athlete to want what they, the trainer, want for them. Needless to say, the athlete is meant to want something that is not entirely impossible, but fairly improbable: an unbroken series of victories. ${ }^{13}$

Thymos, which the trainer tries to arouse in his athlete, ${ }^{\mathbf{1 4}}$ pushes him to overcome the common preconceptions about the limits of possibility, reproducing the category of limitlessness as the only limit term. "In the process,

11 Georges Vigarello, "Stadiony. Widowisko sportowe - od trybun do ekranów," in Historia ciała, vol.3: Różne spojrzenia. Wiek XX, ed. Jean-Jacques Courtine, trans. Krystyna Belaid and Tomasz Stróżyński (Gdańsk: słowo/obraz terytoria, 2014), 341.

Honorata Jakubowska, Gra ciałem: praktyki i dyskursy różnicowania płci w sporcie (Warszawa: PWN, 2014). Peter Sloterdijk, You Must Change Your Life (Cambridge: Polity, 2013), 291. 
the boundaries between the commonplace and the unusual are shifted people increasingly become the creators of self-performed miracles." ${ }^{15} \mathrm{Box}-$ ing, and probably sport as a system in its entirety, is governed by the rule of excessiveness, which is tantamount to affirming boundaries by constantly transcending them.

The essence of a concentration system - as is confirmed by numerous analyses of this phenomenon - rests upon a converse propensity, a drive to obliterate the boundaries separating good and evil, ${ }^{\mathbf{1 6}}$ the perpetrator and the victim, ${ }^{17}$ life and death. ${ }^{18}$ And, finally - between a man and a woman. Milchman and Rosenberg recall in this context the notion of "individual gleichschalten," 19 backed by the Foucauldian thesis of producing docile bodies (they write not only about the camps, but about the system of the Third Reich as a whole - this is important for my further argument), and Catherine Bernard quotes the testimony of women who named depriving them of physiological boundaries that identify womanhood - through actions such as cutting hair, clothing in striped uniforms, the loss of bodily shape and bodily functions (e.g., menstruation) - among the worst acts of cruelty, closely associated with those most viscerally experienced such as devastating labor, malnutrition, and physical abuse, that they were subjected to. ${ }^{20}$ In turn, Bożena Karwowska examines this phenomenon in the context of male prison camps in an interesting way, by analyzing the narratives of Stanisław Grzesiuk, among others, in which the author describes homosexual relations of the prisoners attempting to regain the lost boundary separating masculinity from the unmasculine

15 Sloterdijk, You Must Change, 190.

16 Jean Améry, Poza winq i karą. Próby przełamania podjęte przez złamanego, trans. Ryszard Turczyn (Kraków: Homini, 2007).

17 This diagnosis returns in numerous narratives, most notably in the chapter "The Gray Zone," in Primo Levi, The Drowned and the Saved, trans. Raymond Rosenthal (New York: Simon and Schuster, 1988).

18 This state is explained by Giorgio Agamben - in the context of an Auschwitz football match, by the way - through the example of a camp "Muselmann," an extremely exhausted prisoner of a concentration camp. Giorgio Agamben, Remnants of Auschwitz: The Witness and the Archive, trans. Daniel Heller-Roazen (Brooklyn: Zone Books, 2000).

19 Alan Milchman and Alan Rosenberg, Eksperymenty w myśleniu o Holocauście. Auschwitz, nowoczesność i filozofia, trans. Leszek Krowicki and Jakub Szacki (Warszawa: Scholar, 2003) 298.

20 Catherine Bernard, "Women Writing the Holocaust," Other Voices 1 (2000), accessed October 5, 2014, http://www.othervoices.org/2.1/bernard/womanwriting.php. 
(strikingly, as the researcher points out, the author - though raised in a strongly heteronormative environment - does this in a rather nonjudgmental manner). ${ }^{\mathbf{1}}$

\section{Boundaries and Ruptures of (Male) Community}

The last of the aforementioned aspects of this eradication of difference does not, nevertheless, make it easier to grasp the specificity of the cruel manipulation that was perpetuated by the camp system on the category of masculinity, among others. All in all, Grzesiuk's narrative depicts the mechanism of all hermetical homosocial communities, in which the reconstruction of boundaries between the sexes and of the social roles ascribed to them serves both as a way of regaining normalcy and of exerting violence. Masculinity in extermination camps and in the value system implied by Nazism - for these and previously mentioned reasons - is from the contemporary perspective a highly complicated category as its formation occurred in conditions both similar to previously known circumstances (e.g., planned destruction of ethnic or religious groups, such as the Armenian Genocide), and at the same time framing them as an occurrence without precedent, a rupture in the historical understanding of humanity and its metadescriptive categories, such as masculinity, femininity, and finally humanity itself.22

Irrespective of this circularity it would seem that the understanding of Shoah should be rather considered within the aporetic imaginary. The revolution carried out by thinkers such as Hannah Arendt or Zygmunt Bauman, for example, that reveals the automatism and banality of evil, comes down in the end to recognizing the Holocaust as a rupture, one which emphasized the universal and non-aberrant nature of death's excessiveness. This rupture manifested in the form of crematoriums is final proof of the fact that crematories are the product of capitalist logic which in itself is devoid of any ruptures. When Jean-Luc Nancy attempts to highlight the moment when an attempt

Bożena Karwowska, "Obozy zagłady jako doświadczenie cielesne - przypadek Stanisława Grzesiuka," Przegląd Humanistyczny 2 (2006): 79.

The irresolvable dispute between "the universalists and the particularists," when it comes to thinking about the Holocaust was summarized by Yehuda Bauer this way: "if what happened to the Jews was unique, then it took place outside of history, and it becomes a mysterious event, an upside-down miracle, so to speak, an event of religious significance in the sense that it is not man-made as that term is normally understood. On the other hand, if it is not unique at all, then where are the parallels or the precedents?" Yehuda Bauer, The Holocaust in Historical Perspective (Seattle: University of Washington Press, 1978), 31. 
to perform a gesture of absolute consolidation of communal logic occurs - an attempt to cleanse it of all deviant and excessive elements, leading to a state of absolute immanence - he has the logic of Nazi Germany in mind, ${ }^{23}$ which is a metonymy of the drive to absolutize aberration (in another context, and with a different intention, this was described as the permanence of the state of exception).

Ollivier Pourriol attempts to explain the mechanism of excesses in sport, by analyzing the gestures of contemporary sportsmen. He begins with the memorable incident at the 2006 FIFA World Cup Final in which Zinedine Zidane head-butted Marco Materazzi's torso, when the latter insulted him. In this way Zinedine laid to rest Materazzi's verbal provocations, and for his action he was disqualified in this important, final match. Pourriol dismisses the denouncements appearing in this context of Zidane's purported hubris (hybris), ${ }^{24}$ instead viewing his gesture as induced by thymos - in the same sport-oriented and transgressive interpretation of this notion that was proposed by Sloterdijk - and being a manifestation of his andreia. Therefore, in other words, this gesture was an act of male courage fundamentally different from hubris, and more akin to the whim of Achilles, who through a decision - fully independent from both irrational emotion and cold calculation - to participate in the battle, could have changed the outcome of the Trojan War. A crucial aspect in this whole exchange, Pourriol clarifies, is the bodypart Zidane has chosen to strike. It was not the face - which would be the most hurtful realization of the emotional need of revenge - but the chest, the heart. It was between the head and the heart where Greeks placed the source of thymos - controlled anger - the most noble of masculine forms of courage. This controlled gesture of a street-wise fiend becomes later in Pourriol's book (alongside five other gestures of this kind) a symbol of a sudden, realitytranscending rupture in the social order that is experienced by the sportsmen and which we, as spectators, also experience while participating in an athletic spectacle - the cultural regulation of these natural reflexes arouses universal bewilderment at these communal excesses against the everyday.

The thymos of an athlete inspired by his trainer (to recall Sloterdijk's previously quoted exegesis) therefore transcends all social orders, including the order separating that which is "male" from that which is "female," and at the same time delineates the boundlessness of the sportsmen's wants. The sportsman is constructed as a figure both strengthening the (cultural) order

23 Jean-Luc Nancy, The Inoperative Community, trans. Peter Connor et al. (Minneapolis: University of Minnesota Press, 2004). 
and destroying its (natural, physiologically determined) limits - just like the hero Achilles, whose decision remains beyond good and evil, cowardice (retreating) and courage (partaking). In sport transgression against the norm is simultaneously a basic principle and a source of amazement that entails a reconsideration of the scope and the definition of surpassed limits. Therefore it stands in stark contrast to the ontology of Shoah and its prefiguration, where transgression is a gesture impeding the process of metadescription rather than enabling a redefinition of categories of self-identity. The confrontation of these two orders, in effect, brings to light the way social categories are constructed in the context of a liminal experience, which persecution, genocide, and war undoubtedly are. A vast trove of textual material pertaining to sport and sportsmen experiencing this fate in the 1930 s and 1940 s provides a solid background for such a confrontation.

\section{Boxers and Death}

The archive of narratives interlinking boxing with the Holocaust is surprisingly vast. In Polish literature the persona of Tadeusz Pietrzykowski stands out. ${ }^{25}$ He was a boxer imprisoned in Auschwitz and Neuengamme, who became the hero of two biographies, ${ }^{\mathbf{2 6}}$ one short story, ${ }^{\mathbf{2 7}}$ which was later adapted into a 1962 film directed by Peter Solan; and a number of feature stories ${ }^{\mathbf{2 8}}$ (other Polish boxers from the ghettos and camps - such as Szepsl Rotholc or Antoni Czortek - did not enjoy the same level of interest). In popular literature there is a number of texts worth mentioning - besides numerous narratives of purely historical value - to name a few according to a genre classification: autobiographies (these are among the most numerous, e.g.: Un survivant ${ }^{\mathbf{2 9}}$ or

25 This most interesting of all Polish literary texts in this field (besides the short stories written by Pietrzykowski himself - published as an annex in Marta Bogacka, Bokser z Auschwitz: Losy Tadeusza Pietrzykowskiego (Warszawa: Demart, 2012) was already analyzed by me in greater detail in Paweł Wolski, "Boks w Auschwitz. Sport a przedstawialność Zagłady," in Adlojada: biografia i świadectwo, ed. Jaromir Brejdak, Dariusz Kacprzak and Beata Wolska (Szczecin: Wydawnictwo MNS, 2014). Joanna Cieśla and Antoni Molenda, Tadeusz Pietrzykowski "Teddy" (1917-1991) (Katowice: Towarzystwo Opieki nad Oświęcimiem, OddziałWojewódzki, 1995); and, Bogacka, Bokser ZAuschwitz. Józef Hen, "Bokser i śmierć," in Bokser i śmierć (Warszawa: Czytelnik, 1975). Jarosław Drozd, Bokserzy i śmierć, accessed October 5th, 2014, www.bokser.org/content/2009/07/02/000137/index.jsp. 
Pendu à Auschwitz ${ }^{30}$ ), biographies (e.g. the biography of Hertzko Haft by Alan Scott Haft ${ }^{31}$ ), novels (e.g. The Berlin Boxing Club ${ }^{32}$ ), graphic novels, ${ }^{33}$ film (Triumph of the Spirit, directed by Robert Young or Victor Young Perez, directed by Jacques Ouanich) and many other.

In the aforementioned narratives boxing, almost without exception, reinforces its position of a "stronghold of masculinity," as Honorata Jakubowska calls this sport. ${ }^{34}$ The persona of Hertzko Haft - a poor Jew from Bełchatów, who managed to survive Auschwitz thanks to boxing and later went on to make a boxing career in the Unites States - in both versions of his biography fits into the narrative of a self-made man, a man who is self-sufficient (in this kind of myth the "man" is not a man as such - a human being - but a figure with a predetermined gender), this is one of the most popular myths in all sport narratives that abound in "narrative devices, where $[. .$.$] high on desolate mountain ranges only personal virtue$ can guarantee victory." ${ }^{35}$ In turn, a similarly prevalent theme of manly initiation appears in The Berlin Boxing Club, a fictional story of a young Berlin Jew, who is introduced to boxing by none other but Max Schmeling himself. The fascinating male homoeroticism of boxing matches, that features in the descriptions of Schmeling's silhouette provided by the young narrator, can be also read between the lines of Hen's aforementioned short story, where during the central fight the protagonist:

Rubbed his forehand against Kraft's muscular back, his miserly chest clashed with the mighty, formidably muscular trunk of the other. This reminded him of something. Something pleasant, something he longed for. Oh, he remembered - uncle Stephen. As a child he stepped with his barren feet on his chest, just as broad and hairy, and then uncle Stephen would slowly, very slowly, raise him up into the air in his arms. ${ }^{36}$

30 Sim Kessel, Pendu á Auschwitz (Paris: Solar, 1970).

31 Alan Scott Haft, Harry Haft. Auschwitz Survivor, Challenger of Rocky Marciano (Syracuse: Syracuse University Press, 2006). Robert Sharenow, The Berlin Boxing Club (New York: HarperTeen, 2011).

33 Reinhard Kleist, Der Boxer. Die wahre Geschichte des Hertzko Haft: nach dem Buch Eines Tages werde ich alles erzählen von Alan Scott Haft (Hamburg: Carlsen, 2012).

34 Jakubowska, Gra ciałem, 46.

35 Vigarello, "Stadiony. Widowisko sportowe," 328.

36 Hen, "Bokser i śmierć," 29-30. 


\section{The (Un)manliness of Weimar Sports}

A certain previously unmentioned text deals with the question of masculinity entangled in a complex nexus of political, mythological, microsocial and other types of narratives of 1930 E Europe in a way that allows at least a little distancing from the aforementioned conventionalisms (which in itself does not mean that it is able to escape all of them). The text that I am talking about is Leg dich, Zigeuner, ${ }^{37}$ a double biography of German athletes - Otto "Tull” Harder and Johann "Rukeli" Trollmann. The first was a formidable German footballer, who after returning from the trenches of the First World War longed for the manly, soldierly brotherhood, and who therefore joined the NSDAP, and later the SS. The other was a talented boxer from Hanover, who due to the growing racism in the 1930 (he was a member of the Sinti community) was gradually barred from fighting, stripped of his titles and his boxing license, and finally deprived of his freedom - interned in the KL Neuengamme, and later, under a different name, surname, and number sent to the Wittenberge camp.

Both athletes probably never met, still their parallel lives are constructed by the author in such a manner that they portray a psychomachia of two mutually competing archetypes of manhood. The first of the two heroes relies on the Prussian drill instilled by his father who, in accordance with the nineteenth-and early twentieth-century opinion of the majority of German society, considers football, zealously practiced by his son, as an unmanly and Un-German sport:

German gymnastics teachers, who have monopoly for organizing physical exercise in the garrisons, consider ball-kicking to be futile, undignified, and Un-German. The English restlessly peddle football with monetary interest in mind, but the Germans have their classical gymnastics. (151)

Therefore, according to father, Otto should take up athletics instead. Shot put, long jump, running. On a practice track, where no one is looking. Old Harder would like that. But to kick a ball around, for everyone to see, for team glory [and not that of the individual - P.W.], what purpose is this supposed to serve? Study, work, earn money, bear a son, fight! These are the things worthy of a man. Sport for sport's sake is not one of them. (168)

Otto counters his father's ideal of manhood with another one that is equally mythologized - coerced by his father's beating to refrain from practicing

37 Roger Repplinger, Leg dich, Zigeuner: die Geschichte von Johann Trollmann und Tull Harder (München: Piper, 2008, kindle edition). Further, I will refer to this volume by stating the page number in the text. 
football, he decides that "he will fight pain like a man and like a man he will win that fight" (184). As a result, Otto becomes at the same time the witness and the subject of change, which German and world sport underwent at the time, as "football became something more than a kids' game. Harder and his friends are the first generation to start playing as children and to keep on playing well into adulthood" (467). Onto this narrative of football and footballers' maturing to social responsibility - that is to manliness - a war narrative is superimposed. The life of Otto Harder spans the tumultuous times between the Two World Wars; in both of them sport was for the first time in history used on such a grand scale for military purposes both as a tool of propaganda and for the practical development of fit recruits. Deutscher Fußball-Bund (the German Football Association) proclaimed in 1913 on the pages of its publication: "The Kaiser called to arms all capable men; the first and foremost of them are the members of our organization, who through many years of training prepared their bodies to be ready for action in cases of emergency." And further: "Sport has prepared us for war, so march on the enemy, fear him not, fear nothing" (730). Otto himself already thinks of war in (highly somatic) sport categories:

This is it. [Otto] no longer exists as an individual body. He feels other bodies next to his, as if they were all one, common body. All bodies form a unity. All feel united within that single body, which they form together. He never felt such unity before. It is like the football team, only much stronger. (768)

After the war Harder will voice the frustration felt by the majority of German society: "Newspapers, the reds, Jews - they have destroyed the spirit of victory and have weakened the will. Berlin politicians have thrown in the towel, in contrast to the men fighting on the front. This one thing is certain" (828). This is frustration expressed in the categories of binary opposition between the feminine submissiveness exhibited by traitors of the homeland and the masculine perseverance of its defenders. The former consist of social groups which do not fulfill the ideal of social and national cohesion ("The Jews are responsible for all of this - certain papers would have us believe -and Harder sure believes it," 853), and are therefore responsible for the destruction of the immanence of social roles: "Women adopt manly haircuts and short skirts. Women are lean, while men wear long, slick hair. Fashion changes, the prudery of the Kaiser-era is gone" (828).

War and sport become an antidote for this state of affairs. Another war is clearly in the making and "Tull" Harder is transferred to Waffen-SS seven days before it begins to be posted at KL Sachsenhausen. According 
to the narrator, the camp is the place where he regains the lost feeling of manly, soldierly brotherhood, as the "members of the Totenkopf units consider themselves soldiers, the only thing is they fight in the camps. They are soldiers on «the home front»" (2706). The brotherhood of soldiers is strengthened by the brotherhood of sport: "Harder acts at Sachsenhausen as the coach of the SS football team, moreover, despite his 46 years, he plays for the camp's football team" (2718). This does not change with his transfer to Neuengamme, in November 1939, where he acts as the superintendent of clothing warehouses in the rank of SS-Rottenführer (later he slowly rises in the ranks), organizing at the same time football matches, this time for the prisoners. He does this, as the narrator notes - quoting the testimony of a political prisoner, Herbert Schemmel - charging the prisoners a substantial fee for the privilege (2826).

\section{Boxing's Lost Femininity}

Harder's life story in Repplinger's telling is therefore supposed to depict the era when sport gained the status of a manly, political activity - a status that was by no means obvious until that time. In the Third Reich militarization of certain sport disciplines, already under way during the Kaiser's rule, has truly gained momentum only when the canonized manifest, Mein Kampf, elevated boxing and ju-jitsu above shooting drills in the educational hierarchy of $\mathrm{Na}$ tional Socialist male youth. This entailed a substantial reevaluation in the ontology of sport at that time, and especially in the case of sport practiced by the boxer Rukeli, that is the second - unequivocally positive - protagonist of this book. Boxing, contrary to common perception and despite the often applied nickname "manly art," does not possess such a straightforward gender attribution in its creation story - this is also true of many other disciplines. Georges Vigarello recalls the times when sport was not yet fully professional, that is an activity which - in contrast to its early non-systemic prefigurations ${ }^{\mathbf{3 8}}$ - became in certain ways distinguished from all other activities, but still remained something different from what contemporary sport became - functioning as a proto-industrial system of automatization and categorization. To illustrate this insight Vigarello paraphrases a newspaper account of the first French formally institutionalized football match:

38 Pierre Ignace Chavatte, who plays the numerous sports known to seventeenth-century Lille "when he feels like it or when he has made a bet, without any regularity or discipline, acts in a disorganized and unpredictable way; his actions defy categorization, he does not think of them as something uniform that could make up a system." Vigarello, "Ćwiczyć, grać," 345 . 
The spectators almost intermix with the players in the first match between English and French secondary school students, held in the Bois de Boulogne on March 8th, 1890 - several dozen men in bowler hats, joined by two or three women. ${ }^{39}$

This intermingling of the sexes - it is hard to ascertain whether only among the spectators or also on the playing field - was even greater in boxing, which can seem improbable from a contemporary vantage point. Kasia Boddy mentions the eroticization of the image of fighting women in Ancient Greece (in the works of Ovid, Propertius, and others), ${ }^{40}$ but these early poetic prefigurations are overshadowed by later developments, especially those from the birthplace of the systemic form of modern boxing - eighteenth-century England. An article in The London Journal, from August of 1723, which Boddy quotes, states that "scarce a week passes but we have a Boxing-Match at the Bear-Garden between women," and then she reiterates newspaper announcements with boxing challenges issued by women:

\section{CHALLENGE}

I Elizabeth Wilkinson of Clerkenwell, having had some words with Hannah Hyfield, and requiring satisfaction, do invite her to meet me upon the stage, and box me for three guineas, each woman holding half a crown in each hand, and the first woman that drops the money to lose the battle. ANSWER

I, Hannah Hyfield, of Newgate-market, hearing of the resoluteness of Elizabeth Wilkinson, will not fail, God willing, to give her more blows than words - desiring home blows, and from her no favour; she may expect a good thumping! ${ }^{11}$

It is evident that these early boxing matches between women did not yet possess the form of a rule-bound athletic contest - even though they conformed to socially accepted norms - but they nevertheless were above simple street brawls, which lack any universal and non-immediate context. Boddy refers to, for example, an anonymous print from 1766 (mezzotint on paper) entitled Sal Dab Giving a Monsieur a Receipt in Full, where the titular "Monsieur" stands for a Frenchman humiliated by a British boxer. ${ }^{42}$ This

39

Vigarello, "Stadiony. Widowisko sportowe," 322.

Boddy, Boxing, 24.

Ibid., 28.

Ibid. 
image therefore has a political and nationalistic aspect, and the context in which Boddy places it (a gradual institutionalization of boxing occurring under the conditions of transformation of feudal society into a classbased society and the uncertain, in a way "suspended," role of women in this process), suggests that, at first, boxing - though rooted in the obvious conditions of patriarchal society ("Most reports of women's fighting [all are written by men] focused on the scanty dress rather than the skill of the participants") 43 - was not exclusively a male domain, as was the norm in later times, up until the inclusion of female boxing among the recognized Olympic disciplines in 2012. ${ }^{44}$ Summarizing things briefly, Sal Dab does not symbolize only an additional humiliation of "Monsieur" - as it is handed out by a woman - but it illustrates the relative gender egalitarianism of boxing in its pre-institutional and pre-capitalist faze.

On the other hand, the femininity of male boxers was not always and not everywhere depicted in a negative light, even in the 1930 s when an important part of Roger Repplinger's story of two German athletes is taking place. Two of the most notorious fights of Jack Dempsey were merchandized by contrasting two archetypes of masculinity. Both in his confrontation with Carpentier, who was depicted as a subtle representative of French culture, ${ }^{\mathbf{5}}$ and with Tunney, who was to be an embodiment of composed masculinity based on self-possession, Dempsey was described as an uninhibited, savage brute ${ }^{\mathbf{4 6}}$ (Dempsey had already played this part also in art: Bellows's 1924 painting, Dempsey and Firpo, portrays Dempsey breathing with fury over knocked-out Firpo, waiting for him to get up only to knock him out again; in recent times this role was convincingly played by Mike Tyson). Nevertheless, this does not change the fact that history of boxing is rich in various versions of the myth of manliness attributed to boxers (a feminine perspective has had a substantial influence on the creation of these myths at the outset of the twentieth century, through the works of Rosamond Lehmann, Jane Bowles, Zelda Fitzgerald, and other female writers), $\mathbf{4 7}$ but it also notes such stages of its development when not only men were considered the possessors of boxing courage.

43 Ibid.

44 Women's boxing was included in the 1904 Olympic Games, but merely as a demonstration sport, which can be interpreted as a form of treating this sport as a curiosity event that is subjected in this way to the male gaze.

Vigarello, "Ćwiczyć, grać," 331. Dempsey-Tunney Fights," Journal of American Studies 19 (1985): 27-47. 


\section{Masculinity as a Boxing Spectacle}

To a certain extent the Third Reich imaginary inherits these cultural narratives. This is evident, for example, when different types of manliness are attributed to both fighters in Max Schmeling's first fight with Joe Louis: the first is an exemplar of Nordic self-constraint, ${ }^{48}$ while the second epitomizes the animalistic "instincts of a black panther." ${ }^{49}$ The Nazi vision of boxing's role in the construction of social (as well as sexual) identities are based on another binary opposition that has been codified in 1936 by, among others, Ludwig Haymann - a boxer and the first editor of the NSDAP sports publication Vollkischer Beobachter. This lawgiver of Nazi ontology of sport in his book Deutscher Faustkampf nicht pricefight considers the titular, truly German, fistfight to be the opposite - this is also expressed in the title - of commercialized Anglo-Saxon fighting. Boxing is supposed to prepare individuals for communal life and not to award - in the way of vying for awards ("prizefight"; misspelled in Haymann's work) - individuality (this distrust towards modernity, or rather its one-dimensional treatment by Nazism, as well as the assumption of communal immanence, was expressed by Harder's father in a previously quoted passage). At that, Haymann often turns to the notion of male courage, contrasting the Anglo-Saxon model of distance fighting - that is cowardly fighting - with the German way of direct, and therefore manly, exchange of punches. This principle compelling German fighters is expressed by the author of the story of Tull and Rukeli this way:

[German boxing style] comes down to fighting in lockstep, one body next to the other, a slaughter until the moment when one of the fighters falls, true butchering, without tricks, without bluffs - this is what "German boxing" is like. (2070)

Masculinity in this definition - unambiguous, on the face of it - is nevertheless an amalgam of almost all of its aforementioned models, and especially the combination of unrestrained brutality with the inhibition of the self-preservation instinct (and, what is noteworthy, this resounds with Mayweather's almost identical opinion mentioned previously). Only one model is excluded from their number: agility and cunning - those elements are considered excessive in light of the ideal of a bare fistfight.

48 Lewis A. Erenberg, The Greatest Fight of Our Generation: Louis vs. Schmeling (New York: Oxford University Press, 2006), 73. 
Johann Trollmann, the second protagonist of Repplinger's semi-biographical narrative, begins his boxing career before the ideological and aesthetic kitsch of the Third Reich managed to contaminate the forms of boxing by internalizing such social and gender roles. Nevertheless, boxing has already become a sensitive point of cultural - and gendered - identifications:

In the Weimar Republic one can encounter women with short hair, black, almost naked dancers, a more or less explicit homosexuality, abstract painting, jazz, cocaine, and divorcees. Suddenly people are allowed a lot, here. Part of the German bourgeoisie, which until recently looked up to the upper classes for cultural and social guidance, feels betrayed by its rapid modernization. They wish to return to the nineteenth century, or even to earlier times. They feel threatened, they fear "cultural bolshevism" and "bolshevism" in general. Boxing matches are a way of releasing the pressures building up in this feverish society, which needs to emotionally unburden itself from time to time. On the other hand, sport quite often intensifies emotions instead of calming them. (1086)

Emotions raised by Johann "Rukeli"50 Trollmann - a figure in the public spotlight at least from 1928 - when at an unusually young age for those times he advanced from amateur to professional boxing, ${ }^{\mathbf{5 1}}$ become ever more vague in the circumstances. As a Sinti he is associated with rather unmanly - that is conniving and treacherous - peripheries of society (in line with the logic, which equates fluidity, changeability, deceptiveness with femininity - these preconceptions in relation to the Jewish community were analyzed by Eugenia Prokop-Janiec). ${ }^{52}$ As a boxer he does not fit into the model of masculinity proposed by Haymann and other lawmakers of German sport: instead of engaging in a "masculine," open fight:

Trollmann does not allow the other fighter to close the distance. He almost never confronts his enemy directly. Not of his own choosing anyway, only if the opponent forces him. This is unmanly, but the women

50 This nickname comes from the word "Ruk," denoting a tree in the Sinte language. Its genesis is not clear - it might be associated with Johann Trollmann's extraordinary strength or with his equally uncommon looks. Cf. Yanko Weiss-Reinhardt, "Rukelie."Werwar Johann Wilhelm Trollmann? (San José: Litho Offset, 2004).

51 Weiss-Reinhardt, "Rukelie," 6. Joanna Tokarska-Bakir, "Ganz Andere? Żyd jako czarownica i czarownica jako Żyd w polskich i obcych źródłach etnograficznych, czyli jak czytać protokoły przesłuchań," Res Publica Nowa 8 (2001). 
who frequent his fights in ever greater numbers really like this. What Trollmann does, reminds them of dancing. (1210)

The German press, and Box-Sport in particular, gradually yielding to the pressures of National Socialist politics, uses the disrespectful term "Zigeunertanz" ("Gypsy dance") to characterize Trollmann's fighting style. This designation emphasizes the interrelation between the "unmanliness" of his fighting with the presupposed and disparaged femininity - "fluidity," changeability - of minority populations. Trollmann's "dance" is in fact a part of a broader rhetoric, used to deprive his fights of their manly status, in the Nazi sense of the word. His fights are described as spectacles. Repplinger quotes relevant passages from Box-Sport, which analyze Rukeli's style (e.g."This was a typical spectacle in Trollmann's style, where the gong after the tenth round sounds like the gong of a theater performance," 2416), summarizing them this way:

Trollmann is handsome. He is the "Latin-lover" type, epitomized at the time by Hollywood actor Rudolph Valentino. This draws women to the ring. Some worship him. He sends kisses to the audience during the fight.

[...] Watching Trollmann is a real joy (1711).53

In the essay Masculinity as Spectacle Steve Neal demands a revalorization of masculine perspective in cinema, the interpretation of which is dominated by feminist exegesis. ${ }^{54}$ In Repplinger's narrative the theatrical gestures of Trollmann, and the evident feminine context ascribed to them serve - paradoxically - as a way of constructing masculinity as lavishness (more about this in a moment), which is accomplished through a specific form of visual excessiveness. The sad pinnacle of Trollmann's professional boxing career comes when, dispirited by racist discrimination (also in the form of unfair scoring),

53 What is interesting is that Rudolph Valentino became a hero of a story involving, as was in Trollmann's case, both the subject of masculinity and boxing. Valentino, the symbol of masculinity in its ambivalent incarnation (the film parts of a dancer and sheikh - figures considered feminine by Western culture - reinforced the rumors of his homosexuality), turned to boxing as a symbol of unquestionable manliness, when he decided to challenge to a boxing match a Chicago Tribune journalist who called him a "pink powder puff," after the actor appeared in a powder commercial. Later that year the Everlast company, present on the market until this day, published an advertisement proclaiming: "Many a «Powder Puff» boxer developed a «kick like a mule's» that changed him to a «knockout artist» through the use of the Everlast Training Bag," Boddy, Boxing, 223.

54 Steve Neale, "Masculinity as Spectacle: Reflections on Men and Mainstream Cinema," in Screening The Male. Exploring Masculinity in Hollywood Cinema, ed. Steven Cohan and Ina Rae Hark (London: Routledge, 1993). 
he stands to fight Gustav Eder, in July 1933 in Berlin, with his face powdered in white, and, what is more, he completely changes his fighting style: instead of sways and fast footwork ("Gypsy dance") he decides on a direct, devastating exchange of punches (and in effect loses the fight; 2320). In short: he performs the kind of masculinity which was designed by the German system.

\section{Masculinity as Impasse, Masculinity as Excess}

In the analyzed book, the ethos of masculine sportsmanship in the Third Reich manifests itself most clearly - and in a somewhat banal way - in its final parts, where the reader is introduced to Rukeli's camp story and Harder's post-war experiences. The latter is plainly a negative presence within the narrative, even though the narrator meticulously documents the prisoners' testimonies that attest to his relatively proper behavior in the camps (e.g. "When it comes to the Commandant [Harder - P.W.] himself, there was a consensus in the camp that - according to Szyj Lajzerowicz - «he was a very decent man. It seemed as if he did not mind the prisoners at all [...]». Lajzerowicz also says that Harder never hit anyone, Fajlowicz has also «never seen him beating or mistreating anyone»," 3010). This negativity is constructed through manipulating the themes concerning sports, among other things. Harder's profit-seeking is very prominently featured (e.g. in the previously quoted fragment in which he charges the prisoners on the side for participating in a football match, 2826) alongside his supposedly stellar belief in the Third Reich's sports system, which sought to remake sport as a purely amateur domain, and therefore a human activity devoid of any monetary compensation (2145). Nevertheless, in the context of deliberations on the subject of masculinity there are other more important circumstances that underpin the negativity of this persona. His sport andreia, in contrast to Trollmann's case, is constructed upon the principle of deficiency, and therefore is closer to the previously described destructive Nazi ontology. Harder follows the ethos of male-soldier-sportsman to the extent in which (in Repplinger's narrative) he is lacking something. Finally, reassessing his service in the SS (in the background of this narrative revision the actual post-war process of war criminals, based on court proceedings, is taking place), the narrator concludes that despite lack of direct acts of violence towards the prisoners Harder is nevertheless guilty of the sin of soldierly unmanliness, because of the unevenness in the game he plays (sic!):

In the camp the SS soldiers had no enemies, there were only victims, who could be killed with a single powerful punch. There is no glory in the fight against such an opponent, because there is no risk. [...] Untermenschen have no dignity, they do not command respect. Therefore he who treats 
them disrespectfully cannot lose glory, which he therefore does not possess. (4365)

The narrator in this summary of the heroes (un)manliness does not, contrary to expectations, refer to the arguments known from Eichmann's trial about the lack of direct involvement in the acts of murdering people; but instead decides to determine his culpability on the basis of the ethos of manliness that is constructed by sport (therefore adopting, as if unwittingly, a Nazi perspective). In other words, the narrator utilizes the logic presented in the classical essay on the semiotics of the notion of fear and shame by Yuri Lotman, who, in turn, considers both of the concepts to be complimentary systems. ${ }^{55}$ Sport is based on the transgression against the commands of the fear system with a concurrent respect for the system of shame. The logic of the narrator of the book in question finds fault with Harder as he reverses these transgressions: he behaves "shamelessly," even though he is bound by the topos of sport manliness (which he at the same time adopts as his line of defense: "Harder from the playing field is the genuine Harder. That is how he was. That is how he was also in the camp," 4771)which should incline him to the opposite transgression, that is "fearlessness." This state of affairs was in fact previously noted within the narrative in a curiously corporeal and already quoted description of the comfort Harder experienced in the manly-sports company ("[Otto] no longer exists as an individual body. He feels other bodies next to his, as if they were all one, common body. All bodies form a unity. All feel united within that single body, which they form together. He never felt such unity before. It is like the football team, only much stronger"). Harder's masculinity is realized through an internalization within a homosocial community, and therefore through the loss of the perception of difference, which results in the inability of identification.

In contrast to Harder the manliness of Rukeli, symbolized by sport, exhibits in a manner which I attempted to extract previously from the fascinating analyses of Ollivier Pourriol. Rukeli's andreia is pure lavishness, a hiatus transcending other social distinctions. This lavishness is not only exhibited as spectacle (most clearly at the time he "played the Aryan" when fighting Eger with a powdered face), but even becomes impossible to conceal. Western culture is familiar with the topos of the recognition of the hero (e.g. Odysseus returning to Ithaca), also

55 Jurij Lotman, "O semiotyce pojęć «wstyd» i «strach» w mechanizmie kultury," trans. Jerzy Faryno, in Semiotyka kultury, ed. Maria Renata Mayenowa and Elżbieta Janus (Warszawa: PIW, 1975), 204. The researcher relies on the example of eighteenth-century aristocratic culture in his analysis of the notions of fear and shame, whereas I transplant these notions into the context of 2oth-century ethics of sport, which they elucidate with no less aptitude. 
in the context of manliness (Achilles' andreia is so powerful that, despite being disguised as a woman, he is instantly recognized by Odysseus and Diomedes), but the reading of Holocaust boxing narratives leads to the conviction that this topos gains a distinctive status in this genre, which is striving for autonomy. ${ }^{\mathbf{5 6}}$ In fact all boxer protagonists of these narratives attempt to conceal the (supposedly manly) stigmas indicating their boxing past, as they know that revealing them will lead to involuntary participation in fights, which alongside better treatment pose the risk of unending challenges - also beyond the ring - as well as death, if for some reason they fail to satisfy the organizers. For example, the plot of the previously mentioned story by Hen begins with the identification of the hero (Janusz Kominek) by the Commandant (Walter Kraft) of an unnamed camp, as the boxer's flattened nose is a telltale sign of his profession. In Repplinger's narrative Rukeli at first "does not know if the SS soldiers recognized him. Of course, he thinks, it would be much better if they didn't" (3663), in the end "Luetkemeyer [Commandant of KL Neuengamme - P.W.] stared at him for a long time. Not the way he normally looked at prisoners. He recognized a boxer in him. Trollmann knew this at once" (3980). This moment of boxing lavishness, excessiveness of corporeality, that is impossible to conceal, is also the moment when a gradual dissolution of his life story begins, ending with the death at the hands of a kapo. The climax of this story occurs at the moment of the eruption of lavishness, accumulated in sport in which various ideals of masculinity intersect. Both of these strongly mythologized narratives - of sport and of masculinity - draw from the "imaginary of extremeness, overcoming successive boundaries; this is that «struggle for more»."57

\section{Conclusions}

In 1933, to celebrate the upcoming Olympic Games in Berlin (that were, by the way, the first event since Baron de Coubertin revived the Olympic ideal, to have the torch lit from a flame burning in Greece, the cradle of civilization - a cultural connection which the Third Reich wanted to emphasize) Polish Ministerstwo Wyznań Religijnych i Oświecenia Publicznego [The Ministry of Religious Affairs and Public Enlightenment] held a contest as a result of which Stanisław Zaleski's ${ }^{58}$ sport short stories were published in a collection entitled Największe

56 I explore this problem in greater detail in PawełWolski, "Zagadywanie katastrofy. O literaturoznawstwie Holokaustu," Poznańskie Studia Polonistyczne 24 (2015).

Vigarello, "Stadiony. Widowisko sportowe," 325.

58 Stanisław Wincenty Zaleski, Największe zwycięstwo: opowiadania sportowe (Warszawa: Główna Księgarnia Wojskowa, 1933). 
zwyciesstwo [The Greatest Victory]. The titular greatest victory is achieved by a boxer - and over a woman, at that. Moreover, he achieves it together with his manager, and in league with his athletic adversary, who, just like him, is manipulated by a common lover. The hero, Jerzy Trzon, introduced in the first paragraphs as a symbol of enduring and solid masculinity, is an emigrant who falls in love with Anna, who, in turn, turns out to be a malicious, greedy, and unfaithful woman, taking advantage of his sport and financial successes and falling into the arms of his rival the moment his fortune turns. Nevertheless, the masculine fraternity is unwavering in this narrative; it is enough to say that beyond this short story a figure of an honest and caring manager (not a coach or sparring partner) is practically unheard of in boxing literature. Therefore, if the main protagonist and his manager (customarily depicted as a purely profit-seeking individual), and even the protagonist's rival all support each other, this means we are dealing with a perfect community. This kind of community is a Greek ideal, to which the "new" Germany aspired during the 1930s and 1940s. It is homogenous (also in the sexual sense), transparent, and consists only of Penelopes, never Xanthippes. Today this narrative elicits only amusement, but it might deserve a closer reading, without undue conceit. For what reason is this straightforward story - free of any irritating irregularities except for womanhood, which is, by the way, removed (in an absolute sense) in the final paragraphs of this happy-end narrative - not recognized in contemporary sport narratives? The answer is simple, contemporary stories feed on the principle of lavishness, on physical overabundance. Harmony, which was supposed to be the objective of sport kalokagathia was subverted precisely by this pursuit of homogeneity, by an attempt to internalize human categories, predominantly those related to the body, by Nazi axiology. This absolutization tipped the scales and from then on masculinity, femininity, and other contingent categorizations became examples of excessiveness in contemporary sport narratives. And precisely for this reason, paradoxically, the powdered face of a "dancing Gypsy," Johann "Rukeli" Trollmann - immortalized in the Berlin Kreuzberg in the form of a small memorial - can be a symbol of masculinity until this day. In turn, Mayweather's machismo, described in the initial part of this text, can only be apprehended in the terms of a profit-oriented performance of contingent roles, among which masculinity seems to be the least credible. ${ }^{59}$

Translation: Rafat Pawluk

59 A separate, interesting direction of enquiry would involve exposing the orientalism of the hip-hop, "gangsta" pose and its attributes, such as lavishness and the retaining of a harem, in the context of the feminization of Oriental men performed by Western civilization (of course taking into consideration that this phenomenon was conceived within the framework of that civilization). 